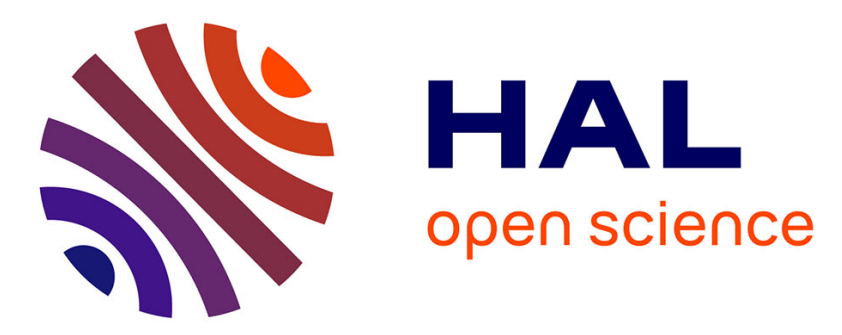

\title{
Comparison of wastewater treatment efficiencies in packed bed bioreactors according to the nature of materials
}

\author{
Chen Wang, Isabelle Bourven, Abdel Lakel, Michel Baudu
}

\section{To cite this version:}

Chen Wang, Isabelle Bourven, Abdel Lakel, Michel Baudu. Comparison of wastewater treatment efficiencies in packed bed bioreactors according to the nature of materials. Journal of Water Process Engineering, 2019, 29, pp.100790 -. 10.1016/j.jwpe.2019.100790 . hal-03487030

\author{
HAL Id: hal-03487030 \\ https://hal.science/hal-03487030
}

Submitted on 20 Dec 2021

HAL is a multi-disciplinary open access archive for the deposit and dissemination of scientific research documents, whether they are published or not. The documents may come from teaching and research institutions in France or abroad, or from public or private research centers.
L'archive ouverte pluridisciplinaire HAL, est destinée au dépôt et à la diffusion de documents scientifiques de niveau recherche, publiés ou non, émanant des établissements d'enseignement et de recherche français ou étrangers, des laboratoires publics ou privés.

\section{(ㄷ)(1) $\$$}

Distributed under a Creative Commons Attribution - NonCommerciall 4.0 International 
1 Comparison of wastewater treatment efficiencies in packed bed bioreactors according to the

2 nature of materials

3 Chen WANG ${ }^{1,2}$, Isabelle BOURVEN ${ }^{2}$, Abdel LAKEL ${ }^{1}$, Michel BAUDU ${ }^{2 *}$

4

$5{ }^{1}$ Centre Scientifique et Technique du Bâtiment, 11, Rue Henri Picherit, 44323, Nantes, France

$6{ }^{2}$ Groupement de Recherche Eau, Sol et Environnement (GRESE), University of Limoges, 123 av 7 Albert Thomas, 87060 Limoges, France

8

9

10

11 *corresponding author: michel.baudu@unilim.fr 


\section{Abstract}

Due to over-exploitation, river sands are less available in certain areas. Other materials are substituted for use as packing materials, e.g. crushed aggregate resulting from the quarrying of massive rocks is considered a potentially suitable material. However, the real impact of this substitution on water treatment efficiency are not mastered because all available works was carried on small scale pilot and only during the first step of colonization. The present work compares the purification efficiencies of two river sands (RS1, RS2) and two crushed aggregates (CA1, CA2) using backed bed bioreactors over a 360-day operating cycle. The total suspended solids (TSS), organic removals and ammonium removals display similar removal rates except for the coarse river sand. The total nitrogen removal is limited for all materials. Statistical analysis indicates that pollutant removals mainly depend on both grain size (effective size: $\mathrm{D}_{10}$ ) and the size uniformity coefficient (UC). Furthermore, a low $\mathrm{D}_{10}$ and $\mathrm{UC}$ also favor the presence of an anoxic environment and may improve denitrification. The crushed aggregate, as a potential substitution for river sands whose deposits are becoming depleted, may provide similar treatment functionality, namely suitable pollutant removals and biomass support.

Keywords: packed bed bioreactor; filtration; purification; river sand; crushed aggregate; biomass. 


\section{Introduction}

On-Site Wastewater Treatment (OWTS) plants typically comprise a septic tank for primary wastewater treatment and infiltration/filtration systems (featuring soil infiltration or sand filtration) for secondary treatment. The septic tank enables solid/grease/liquid separation and settling, in addition to the hydrolysis processes of solids, digestion of certain organic matter and transformation of organic nitrogen into ammonium [1]. Pre-treated effluent, known as septic effluent, which is considered a source of groundwater contamination and water resources eutrophication in the presence of phosphorus and nitrogenous pollutants and microorganisms [2-3]. This septic effluent is spread over soil absorption fields or sand filtration systems flowing under unsaturated conditions. Packed bed bioreactors are used for very different water treatment objectives like domestic sewage or synthetic industrial wastewater [4-6]. For OWTS, unsaturated filtration treatments are often applied in conjunction with on-site soil absorption fields. Soil conditions however are sometimes unsuitable for wastewater treatment, hence the soil reconstruction with other packing materials is needed; the most widely used filter medium is natural sands from alluvial deposits, e.g. river sands. Grain size distribution is the most important characteristic of a porous medium. French and American authorities have imposed particle size distribution of a filter medium. Liénard et al. [7] have also suggested a narrower range for $\mathrm{D}_{10}$ (i.e. $0.2 \mathrm{~mm}<\mathrm{D}_{10}<0.4 \mathrm{~mm}$ ) so as to ensure an effective purification process. The discontinuous feed maintains the filter medium unsaturated and aerated, in addition to facilitating aerobic bacterial growth; consequently, sand filters can be considered as aerobic fixed-biomass reactors [8]. Rodgers M. [9] considered that biomass developed inside the filter medium contributes to purification performance via the degradation of organic matter consumed by heterotrophic 
bacteria. The purification process is influenced by both environmental and operational conditions, such as: temperature, packing material characteristics, hydraulic loading, organic loading, and dosing frequencies [8-12].

Due to over-exploitation, river sands are less and less available as packing bed materials. Crushed aggregate resulting from the quarrying of massive rocks is considered a potentially suitable material. Some studies have shown that crushed aggregate offers a very broad size distribution with angular, irregular particle shapes $[3,13]$. The lack of scientific base of filter conception don't permit a good potential information on the long-term functioning. Research works have been made with the purpose of finding the correlation between filter sizing and long term functioning (clogging). Authors tented to propose the operating conditions and sizing criteria provide a balance between necessary nutrients loads and clogging produced by organic and particulate matters accumulation [14]. Later, design criteria have been improved since more full-scale soil infiltration beds and sand filters have been investigated by Jenssen \& Siegrist [15]. Investigations of clogging lead to three major mechanisms: pore blocking caused by suspended solids [16]; over developed biomass and accumulation of extracellular polymers secreted, such as proteins and polysaccharides [17] and precipitation of certain metals such as $\mathrm{FeS}$ and $\mathrm{CaCO}_{3}[18]$. Fewer studies have based on the clogging process and packing materials characteristics.

Thus, the real impact of solid particles shape and surface proprieties are never investigated and how the materials of different nature impact the development of clogging or the purification efficiency remains unclear. Only one study on small scale pilot unit and only during the first step of colonization (1 month) [19] seems to show similar efficiencies for organic and suspended 
solids removal with river sand and crushed aggregate. For a better knowledge on the influence of packing bed material and a more complete information about the potential substitution of sand in OWTS, we have conducted this study using real septic effluent with various filter materials and the purification efficiency was monitored throughout the year following process startup.

\section{Materials and methods}

\subsection{Packed bed materials}

Two natural materials (river sands RS1 and RS2) and two crushed aggregates (CA1 and CA2) were tested. The packing material characteristics are displayed in Table 1. The influence of effective size $\left(\mathrm{D}_{10}\right)$, uniformity coefficient and packing material chemical composition (divalent cations $\mathrm{Ca}^{2+}$ and $\mathrm{Mg}^{2+}$ ) on the treatment efficiencies were studied and taken into account for purposes of statistical analysis. Statistical analysis was performed with the SYSTAT 12 program (Systat Software, Inc.). A $p$ value of 0.05 was established as the parameter level of significance on treatment efficiency in the steady state. For $p$ values of less than 0.05 , the parameter was considered to exert influence on the treatment efficiency.

Pictures of the sand samples were processed by ImagJ Software. After an 8-bit binary conversion, the picture scale was set and the particle analyses performed with a dedicated plugin. The filter was introduced with limitations to both its size $(0.1-4 \mathrm{~mm})$ and circularity $(>0.75)$ so as to ensure effective particle isolation. Two parameters were determined:

Circularity $=4 \pi \times($ Area $) /(\text { Perimeter })^{2}$;

Roundness $=4 \times($ Area $) / \pi \times(\text { Major axis })^{2}$. 


\subsection{Pilot batch experiment}

The reactor configurations and feeding conditions are described in Table 2. The experiment was carried out on a laboratory-scale pilot equipped with 12 columns $30 \mathrm{~cm}$ in diameter featuring 3 different heights: 15,30 , and $70 \mathrm{~cm}$. French standards recommended the material layer of $70 \mathrm{~cm}$ as real scale sand filtration bed practice. The feed water was stored in a mixed storage tank and replenished roughly every 7 to 10 days. Figure 1 provides an overview of the reactor set-up. The feed water was spread by the distribution disk perforated with 15 holes. These experiments were conducted in a controlled environment at $20 \pm 2^{\circ} \mathrm{C}$. The columns were discontinuously supplied with 10 batches of septic effluent in order to maintain the unsaturated conditions. The hydraulic loading was set at $12 \mathrm{~cm} /$ day for all reactors, except columns 10 and 12 , which were set at 20 $\mathrm{cm} /$ day.

Hydraulic conductivities were estimated by infiltration tests using the columns with an 8 -cm diameter and 20-cm height [7]. The hydraulic residence time (HRT) was characterized in the 30and $70-\mathrm{cm}$ reactors by instantly injecting inert tracer lithium chloride $(\mathrm{LiCl}, 1 \mathrm{~g} \mathrm{Li} / \mathrm{l})$ and monitoring Li concentration in the treated effluent. Li was analyzed using Atomic Absorption Spectroscopy (SpectrAA 220, VARIAN).

In an initial step, the depollution performance was compared by running filtration reactors with a $30-\mathrm{cm}$ diameter and 30-cm thickness on four different packing materials (river sands RS1 and RS2, and crushed aggregates CA1 and CA2) because the upper 30-cm filter medium is the more active part in a vertical filtration bed [18]. Operational parameters were modified on two selected materials for subsequent comparisons; these parameters were bed thickness and hydraulic 
loading. The depollution efficiencies with four different filter materials were monitored in terms of: particulate matter (TSS), organic matter with a Chemical Oxygen Demand (COD) determination, nitrogenous pollutants (ammonium, nitrates and total nitrogen), and phosphate pollutants.

\subsection{Characterization of feed water and treated effluent}

The feed water was collected from the septic effluent tank. Its main characteristics were monitored throughout the operating period. The average values of each characteristic are listed in Table 3. The feed water and treated effluent from 12 columns were characterized by physicochemical analysis conducted with Spectroquant ${ }^{\circledR}$ photometric testing (Merck). The chemical oxygen demand (COD) was determined according to the rapid-digestion method (EN ISO 15705); total nitrogen (TN) was derived after decomposition with potassium peroxodisulfate (EN ISO 11905-1); ammonium $\left(\mathrm{NH}_{4}{ }^{+}\right)$and nitrates $\left(\mathrm{NO}_{3}{ }^{-}\right)$were found by applying the indophenol blue method and dimethylphenol method (EN ISO 7890-1), respectively; and lastly orthophosphates $\left(\mathrm{PO}_{4}{ }^{3-}\right)$ were determined by the phosphomolybdenum blue method (EN ISO 6878). Suspended solids were measured by weight loss after heating to $105^{\circ} \mathrm{C}$ for $24 \mathrm{~h}$. The feed water and treated effluent were stored in open systems; hence, the dissolved oxygen $\left(\mathrm{O}_{2}\right)$ and nitrite $\left(\mathrm{NO}_{2}{ }^{-}\right.$, DIN EN 26777) values were not recorded. An oxygen gas evolution test over $24 \mathrm{~h}$ with the finer materials (RS1 and CA1) confirmed that the reactors of $70 \mathrm{~cm}$ remained oxygenated at the beginning of the operation (see Table 2). The microbiological parameters were only monitored at the end of the process on the $70-\mathrm{cm}$ columns with viable aerobic flora (EN ISO 6222:1999). All feed water characteristics are summarized in Table 3. 


\subsection{Material characterization during the process}

The total organic matter attached to the various materials was quantified in terms of volatile dry weight (VDW), with the weight loss of sampled materials being measured by incineration between $105^{\circ}$ and $550^{\circ} \mathrm{C}$ [19]. The total organic distribution across the depths of the four materials was evaluated at the end of the second study period.

The bacterial flora was extracted from the three different layers in river sand 1 and crushed aggregates 1 and 2 at the end of the first period. A 20-g mass of colonized materials was sampled from $0 \sim 5 \mathrm{~cm}, 10 \sim 15 \mathrm{~cm}$ and $30 \mathrm{~cm}$. These materials were then washed with $100 \mathrm{~mL}$ of a $9 \%$ $\mathrm{NaCl}$ solution, and $10 \mathrm{~g}$ of washed sample were extracted using a $20-\mathrm{mL}$ phosphate buffer $(0.1 \mathrm{M}$ at $\mathrm{pH}=8.0$ ) by sonication for $15 \mathrm{~min}$. The suspended slurry was then diluted and inoculated with nutrient agar for aerobic heterotrophic flora $(n=2)$. The nitrifying bacteria were also assessed with a liquid medium (ISO 4831:2006). $200 \mu \mathrm{L}$ of diluted extracted sample were added to $1.8 \mathrm{~mL}$ of liquid ammonium medium $\left(\mathrm{N}-\mathrm{NH}_{4}, 0.6 \mathrm{~g} / \mathrm{L}\right)$ that also contained bicarbonate anions $\left(\mathrm{NaHCO}_{3}, 1\right.$ $\mathrm{g} / \mathrm{L}$ ) at $\mathrm{pH}$ 8.2. After 72 hours of incubation at $30^{\circ} \mathrm{C}$, the presence of nitrites was revealed by adding sulfuric acid and alpha-naphtylamine (reagent Nit 1 and Nit 2 of analytical profile index: API20E) into each tube. In the absence of nitrites, zinc powder was added to recover the nitrates $(n=5)$.

FDA (fluorescein-diacetate (3'-6' diacetyl-fluorescein)) hydrolytic activity was determined by the enzymatic assay procedures [20]. A 0.5-g mass of colonized CA materials was sampled from $0 \sim 5 \mathrm{~cm}, 10 \sim 15 \mathrm{~cm}$ and $30 \mathrm{~cm} .0 .5 \mathrm{~g}$. Material was placed into a $50 \mathrm{~mL}$ Erlenmeyer flask. 20 $\mathrm{mL}$ of $60 \mathrm{mM}$ sodium phosphate buffer (pH 7.6) and $100 \mu \mathrm{L}$ of $4.8 \mathrm{mM}$ FDA were added into the flask. Samples were incubated for $60 \mathrm{~min}$ on a shaker at room temperature. After $60 \mathrm{~min}, 10 \mathrm{~mL}$ 
of acetone were added to terminate the hydrolysis reaction. Samples then were centrifuged for 5 min and Fluorescein (the product of FDA hydrolysis) concentration was determined spectrophotometrically at $490 \mathrm{~nm}$.

The phosphate sorption kinetic tests were also performed on all four materials. $200 \mathrm{~mL}$ of phosphate solution of $20 \mathrm{mg} \mathrm{P}_{-} \mathrm{PO}_{4}{ }^{3-} / \mathrm{L}$ (prepared from $\mathrm{Na}_{2} \mathrm{HPO}_{4}$ ) at $\mathrm{pH}=7$ was added to $20 \mathrm{~g}$ of each material. The batches were mixed at $110 \mathrm{rpm}$ during 24 hours. The mixture were sampled at 0, 30min, $1 \mathrm{~h} 30,5 \mathrm{~h}, 10 \mathrm{~h}$ and $24 \mathrm{~h}$, and the $\mathrm{P}_{-} \mathrm{PO}_{4}{ }^{3-}$ concentrations were measured with $0.45 \mu \mathrm{m}$ filtrates.

\section{Results}

\subsection{Impact of materials on treatment efficiencies}

The first part of this study investigated the efficiency of 4 reactors with varied materials through several parameters: TSS, nitrogen forms and phosphates. The filtration reactors with a $30-\mathrm{cm}$ active layer were fed with inlet water at a rate of $12 \mathrm{~cm} /$ day. The results obtained over 360 days of operations are presented in Figure 2. The TSS removals (Fig. 2a) shows similar and satisfactory efficiency rates with the finer river sand (RS1) and both crushed aggregates (CA1 and CA2) after 60 days of operations. RS1 demonstrated quick and effective removals at the beginning of the process. In contrast, the coarser river sand (RS2) yielded lower and less stable TSS removals throughout the operations, i.e. typically below $80 \%$. COD removals behaved similarly to TSS. The coarser river sand (RS2) was rated at the lowest efficiency $(<70 \%,>125$ $\mathrm{mgO}_{2} / \mathrm{L}$ ) throughout the operating period, while the finer river sand (RS1) and crushed aggregate 1 (CA1) exhibited similar removal rates (85\%, $60 \mathrm{mg} \mathrm{O} / \mathrm{L}$ ) after running for 120 days (Fig. 2b). Compared to RS1, the two crushed aggregates took longer (100 days for CA1, 180 days for CA2) 
to reach a similar efficiency level. The effective size of materials has shown a most significant correlation (treatment efficiency increased with a decrease in effective size) in both TSS and COD removals (significant at $\mathrm{p}=0.001<0.05$ for TSS and $\mathrm{p}=0.007<0.05$ for COD). The material uniformity coefficient also indicated a slight correlation with COD removal $(\mathrm{p}=0.04<0.05)$. Even though an increase in removal rate can be noticed in RS2, this material still produced the lowest and least stable organic removals.

The nitrogenous pollutants in feed water were dominated by organic and ammonium nitrogen; the nitrate traces were negligible. By relying on sample averaging, the nitrite level in

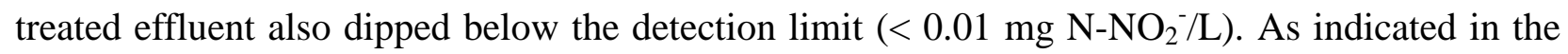
TSS and organic removals, RS1 and CA1 showed similar satisfactory efficiencies in ammonium removals after 100 days (> 95\%), with RS1 displaying early stabilization (at around 45 days) (Fig. 2c). The removals in CA2 indicated slightly less stability (60 120 days). The highly permeable material (RS2) of coarser size did not improve ammonium elimination $(<75 \%)$ due to its poor HRT (Table 2), which led to incomplete nitrification. Similar to TSS and COD, the effective size and uniformity of materials exhibited significant correlations with ammonium removals $(\mathrm{p}=0<$ 0.05 for D10 and $\mathrm{p}=0.0003<0.05$ for UC). Aside from this exceptionally coarse sand, RS1 and the two crushed aggregates revealed no significant difference in ammonium removal after 100 days of operations.

Phosphorus pollutants in the feed water were dominated by phosphates; their removal rates were typically below $60 \%$ (2 9 $\mathrm{mg} \mathrm{P} / \mathrm{L}$ ). Figure $2 \mathrm{f}$ shows that phosphate removals via the filtration reactors were inconsistent and less effective. At the beginning of the process, two CA specimens exhibited higher phosphate removals than the river sands (around 70\% for CA1 and 
CA2 vs. approx. $50 \%$ for RS1). Although the phosphate sorption tests showed no significant phosphate adsorption by all four materials.

\subsection{Degraded conditions}

For RS1 and CA1-packed reactors, reducing bed thickness (from 30 to $15 \mathrm{~cm}$ ) led to lower purification efficiency, especially with respect to organic and ammonium removals. In contrast, the thicker beds improve efficiency and provide for both satisfactory removals and better stability due to the longer HRT (Table 2) [17]. With 70-cm filtration reactors, RS1 yielded slightly better efficiencies in organic and ammonium removals, but also significantly higher total nitrogen removal rates $(39 \%[21 \%, 58 \%]$ for $\mathrm{RS} 1$ and $22 \%[4 \%, 36 \%]$ for CA1).

Another comparison was drawn between an HLR of $12 \mathrm{~cm} /$ day vs. $20 \mathrm{~cm} /$ day using two selected filter media. In sum, increasing the HLR led to a decrease in the HRT value, especially for RS1 (Table 2), along with a slight decrease in the efficiency of several parameters (Table 5): TSS, organic matter, ammonium and total nitrogen, specifically at the beginning of operations when the biomass is still immature. Removal rates gradually rose with operating time, and the bed thickness also compensated for the resistance to hydraulic loads; a higher hydraulic loading significantly reduces organic removal efficiency in shallower beds $(30 \mathrm{~cm})$ [21].

Ammonium removal efficiencies presented fluctuations under higher hydraulic loading, yet both materials seemed to be sufficiently resistant and removals typically remained above $90 \%$ (Figs. 3 and 4). Stabilization was established early under the lower hydraulic loading, notably in the fine river sand (RS1), whereas a longer operating time was needed for both materials at a higher loading. At the beginning of operations, both adsorption and incomplete nitrification were present in the immature system [14]. The higher water flow reduced ammonium adsorption and 
limited the nitrification process $[20,22]$. This impact of hydraulic loading has been confirmed by nitrate contents as well as by total nitrogen removals in the higher loading reactors, where denitrification has considerably limited the reduction in HRT values.

The differences observed between materials can be discussed from the implantation of the biomass in the reactors.

\subsection{Filter materials and biomass distribution}

Given the observations recorded for the various filter media at the end of the study, total organic contents (expressed as volatile dry weight, i.e. $\mathrm{mg}$ VDW/g of material) could be assessed by core sampling from 3 layers in the filtration reactors $(0 \sim 5 \mathrm{~cm}, 10 \sim 15 \mathrm{~cm}$ and $30 \mathrm{~cm})$ following process stabilization (Table 6). Due to poor colonization onto coarse sand (RS2 with a VDW of $3.69 \mathrm{mg} / \mathrm{g}$ ), cell extractions were not carried out with this material. Total organic contents decreased from the top layer throughout the bed in all materials studied. The fine river sand (RS1) showed higher accumulations at the surface and less organic matter in the deeper part. The total VDW is highest for RS1, in accordance with grain size (see Table 1, average grain diameter of $0.82 \mathrm{~mm}$ for RS1, vs. $2.66 \mathrm{~mm}$ for RS2). The organic matter accumulation results matched the correlation between the TSS, COD removals and the effective sizes shown in Section 3.1 ( $\mathrm{p}<$ $0.05)$.

The results of total viable aerobic heterotrophic flora and autotrophic nitrifying flora are listed in Table 7. The distribution of heterotrophic bacteria in the fine river sand (RS1) appears to be higher in the top $15 \mathrm{~cm}$ than the deeper layer, which follows organic matters accumulation pattern especially at the top regarding the VDW values. The distribution of autotrophic nitrifying bacteria 
is less prevalent at the surface of the three filter media since the presence of higher substrate concentrations favors the growth of heterotrophic flora. The results showed that, for the fine river sand (RS1), nitrifying bacteria are mainly concentrated in the 10 15-cm layer but not in the deeper part $(30 \mathrm{~cm})$, where as they were embedded relatively deeper in the crushed aggregate (CA1 and CA2).

\section{Discussion}

A medium composed of finer material enabled earlier stabilization in both TSS (particulates) and organic matter (particulates and dissolved forms) removals under the action of mechanical retention at first by the reactor surface layer [19], and then uptaken by the increased biomass (Table 4) [23,24]. The cumulative particulate pollutants and heterotrophic biomass growth on material over time are expected to contribute to increased TSS removals [25], and the hydrolysis and assimilation by heterotrophic biomass also played a key role in organic pollutant removals $[6,26,27]$. CA1 and CA2 are relatively coarser media but a lower circularity and roundness coefficients (table 1) leads to a lower organization of the stack and the presence of fine particles reducing pore spaces and increasing surface area. This particularity of crushed aggregate increase efficiency with an accumulation of retained particles. Crushed aggregates exerted no significant impact on either TSS or organic removals, provided an adequate stabilization time has been allocated (i.e. more than 60 days of operations). Consequently, the physical characteristics of materials may influence COD and TSS removals either directly or indirectly (particulate or dissolved organic carbon catabolism affected by the velocity of microbial implantation on the material). The small size could explain the higher TSS retention as well as the higher bacterial implantation due to a greater specific surface area. Results from this study indicated that for a 
filter medium with an average grain size of less than $1.6 \mathrm{~mm}$ (i.e. $\left.\mathrm{D}_{10}<0.44 \mathrm{~mm}, \mathrm{CA} 2\right), 30-\mathrm{cm}$ media were sufficiently effective for TSS removals [9,28]. A narrower range for D10 (i.e. $0.2 \mathrm{~mm}$ $<$ D10 $<0.4 \mathrm{~mm}$ ) so as to ensure an effective purification process have also suggested [7].

As for the COD removal, the material's physical characteristics could therefore impact ammonium removals both directly (portion of ammonium linked to TSS) and indirectly (ammonium oxidation affected by the microbial implantation on the material). An earlier and faster ammonium removal by RS1 (over the first 60 days) was due to assimilation by both bacterial growth (heterotrophic and autotrophic flora) and TSS retention, which takes place higher in the top layer of river sand. On the other hand, TN removal is limited (to around 20\%) for all materials (even lower for RS2) with no improvement in incubation time (Fig. 2e). Rodgers et al. [23] have demonstrated that unsaturated sand filters often yield low total nitrogen removals due to a slight denitrification under aerobic conditions. Relatively higher TN removals have been observed on a real scale constructed of wetland and soil trenches (Table 4) [10,29]: the presence of local suitable conditions for denitrification was facilitated by the long-term accumulation of organic matter (particulates and biomass). In the four reactors studied, results indicate that the denitrifying bacteria activities never take place inside the reactor due to overly-saturated conditions. However, the relatively higher phosphate removals by four materials during the earlier operation (Day 0 to Day 360) might be related to the biological assimilation. No adsorption capacity was shown with any of the materials, due to their nature of material surface, which contains mainly the oxide of silica and results in slightly negative surface charge [30]. Authors suggested that a stratified packed bed reactor using dolochar as filter material is capable for phosphate removal due to its composition, which contains mainly the carbonates of calcium and 
magnesium; the prediction breakthrough and exhaustion time can be relayed by increasing bed thickness and initial phosphate concentration or by decreasing the flow rate using several bed column models [31].By drawing another comparison between RS1 and CA1 with a 70-cm medium, the material characteristics revealed a major influence on total nitrogen removal efficiency. Using the 70-cm reactor packed with RS1, the improved removal rate (39\% [21\%, $58 \%$ ] for RS1, $22 \%$ [4\%, 36\%] for CA1) was due to the more extensive denitrification within the fine medium under low hydraulic loading. Relatively saturated conditions $([11,20] \%$, oxygen gas variation, see Table 2), when the effluent inlet arrives and stagnates at the surface of the fine uniform medium (Table 1), were temporarily created. Moreover, the pore seal caused by an accumulation of particulates and biomass further improved the appearance of local anoxic microsites and favoured denitrification [10]. The denitrification condition was sensitive to a point that increasing HLR led to limiting denitrification by reducing the corresponding HRT value (23\% for RS1 at $20 \mathrm{~cm} /$ day and $39 \%$ for RS1 at $12 \mathrm{~cm} /$ day).

In terms of biomass distribution which plays an important role in purification and pore sealing, both the retention of particulate matters and the straining of bacterial cells suggested that RS1, mechanical filtration is an active surface phenomenon over the top part of the filter (organic matter is included in TSS) thanks to its fineness, and soluble substrate is a limited factor to colonization along the column depth where substrates, bacterial cells and oxygen are relatively concentrated compared to the deeper part $[9,32]$. In contrast, this surface filtration phenomenon does not exist with crushed aggregate (CA1 and CA2). Both revealed a slightly higher penetration of particulates and cells into the beds. Their heterogeneous grain sizes (UC $=5 \sim 10$, while $\mathrm{UC}=2$ for RS1) yields larger pores and a smaller specific surface area, allowing the bacteria to penetrate 
and also be retained in the deeper part of the filters: the distribution of heterotrophic bacteria appear to be homogeneous in the top $15 \mathrm{~cm}$ to the deeper layer even if VDW is higher at the top. More, the colonization of heterotrophic bacteria at the top is lower in CA1 and 2 than in RS1 due to smaller specific surface area. This could impact the clogging velocity at long term at the top layer the more thickness is the biofilter the more efficient it is (table4 COD\%). On the other hand, the concentration of autotrophic nitrifying bacteria in RS1 suggests that their distribution is also limited by another factor: oxygen content. The lower oxygen gas content (Table 2) in RS1 during batch operations (varies from $20 \%$ to $11 \%$ during the rest-batch sequence) indicates a relatively saturated environment and the lack of access to oxygen in the deeper layer. Otherwise, the relatively deeper implantation of nitrifying bacteria in crushed aggregates might be explained by :i) the size heterogeneity and angularity of crushed aggregate, which allow for bacterial migration; ii) the competition with heterotrophic bacteria for $\mathrm{NH}_{4}^{+}$is lower (less viable heterotrophic bacteria after $0-5 \mathrm{~cm}$ ); and iii) the porosities are relatively higher and the media less saturated (e.g. CA1, see Table 2). Some authors have pointed out that nitrifying bacteria are most active in the $10-12 \mathrm{~cm}$ below the infiltrative surface $[15,33]$. However, with a more permeable material, nitrification also occurs between depths of 0.3 and $1 \mathrm{~m}$ in the medium [32].

So, soluble substrate (organic) are metabolized with similarly efficacy from the top to the deeper part in CA biofilter. This is confirmed by the FDA activity upon the biofilter level at day 360 in CA1 and 2 (figure 5). FDA (fluorescein-diacetate (3'-6' diacetyl-fluorescein)) is used for determining total heterotrophic microbial activity. Nevertheless, colonization of the filter by heterotrophic bacteria is not so homogenous: at day 60 and especially day 210 , the implantation of bacteria starts and follow the accumulation of TSS: distribution of heterotrophic bacteria appears 
to be higher in the top $15 \mathrm{~cm}$ than the deeper layer (figure 5). At the first step of colonization in the CA biofilter distribution of heterotrophic bacteria is similar to the stationary step of RS1.

\section{Conclusion}

From the above, bacteria influence the treatment efficiencies (through the final removal value and stabilization time, as described above) of soluble pollutants, especially given that heterotrophic metabolisms remove organic carbon and may cause denitrification in an anoxic environment, while the nitrification metabolism removes ammonium ions. Bioreactor with RS1 material should be more favourable to the denitrification (more heterotrophic bacteria, more anoxic) whereas bioreactor with CA material should be suitable to nitrification. The crushed aggregate, as a potential substitution for river sands whose deposits are becoming depleted, may provide similar treatment functionality, namely suitable pollutant removals and biomass support.

\section{References}

\section{References}

1. Jr. R. B. Reneau, Hagedorn, C., Degen, M.J., Fate and transport of biological and inorganic contaminants from on-site disposal of domestic wastewater, J Environ. Qual. 18 (1989) 135-144.

2. M. V. Yates, Septic Tank Density and Ground-Water Contamination, Groundwater 23 (1985) 586-591.

3. P. J. A. Withers, H. P. Jarvie, C. Stoate, Quantifying the impact of septic tank systems on eutrophication risk in rural headwaters, Environ. Inter. 37 (2011) 644-653.

4. B. Y. Chen, S.Y. Chen, J. S. Chang, Immobilized cell fixed-bed bioreactor for 
wastewater decolorization, Process Biochem. 40 (2005) 3434-3440.

5. A. P. Oliveira Netto, M. Zaiat, Treatment of domestic sewage in an anaerobic-aerobic fixed-bed reactor with recirculation of the liquid phase, Clean Soil Air Water 40 (2012) 965-971.

6. O. Anjaneya O., S.S. Shrishailnath, K. Guruprasad, S. Nayak Anand, S. B. Mashetty, T. B. Karegoudar, Decolourization of Amaranth dye by bacterial biofilm in batch and continuous packed bed bioreactor, Int. Biodeterior. \& biodegrade. 79 (2013) 64-72.

7. A. Liénard, H. Guellaf, S. Boutin, Choice of the sand for sand filters used for secondary treatment of wastewater, Water Sci. \& Technol. 44 (2001) 189-196.

8. R. Kristiansen, Sand-Filter Trenches for purification of septic tank effluent: I. The clogging mechanism and soil physical environment, J. Environ. Qual. 10 (1981) 353-357.

9. M. Rodgers, G. Walsh, M. G. Healy, Different depth sand filters for laboratory treatment of synthetic wastewater with concentrations close to measured septic tank effluent. J. Environ. Sci. Health, Part A: Toxic/Hazard Subst. Environ. Eng. 46 (2011) 80-85.

10. R. Kristiansen, Sand-Filter Trenches for purification of septic tank effluent: I. The clogging mechanism and soil physical environment, J. Environ. Qual. 10 (1981) 353-357.

11. M. Rodgers, G. Walsh, M. G. Healy, Different depth sand filters for laboratory treatment of synthetic wastewater with concentrations close to measured septic tank effluent. J. Environ. Sci. Health, Part A: Toxic/Hazard Subst. Environ. Eng. 46 (2011) 80-85.

12. P. R. Rout, R. R. Dash, P. Bhunia, S. Rao, Role of Bacillus cereus GS-5 strain on simultaneous nitrogen and phosphorous removal from domestic wastewater in an inventive single unit multi-layer packed bed bioreactor, Bioresource Technology. 262 (2018) 251-260.

13. G. Cho, J. Dodds, J. Santamarina, Particle shape effects on packing density, Stiffness, and Strength: Natural and Crushed Sands, J. Geotech. Geoenviron. Eng. 132 (2006) $591-602$.

14. K. A. Healy, R. Laak, Site evaluation and design of seepage fields, J. of the Sanitary Eng. Division 100 (1974) 1133-1146.

15. P. D. Jenssen, R. L. Siegrist, Technology assessment of wastewater treatment by soil infiltration systems, Water Sci. \& Technol. 22 (1990) 83-92. 
16. J. De Vries, Soil filtration of wastewater effluent and the mechanism of pore clogging. Water Pollut. Control Fed. 44 (1972) 565-573.

17. A. Torrens, P. Molle, P., C. Boutin, M. Salgot, Impact of design and operation variables on the performance of vertical-flow constructed wetlands and intermittent sand filters treating pond effluent, Water Res. 43 (2009) 1851-1858.

18. A. J. Cooke, R. K. Rowe, B. E. Rittmann, I. R. Fleming, Modeling biochemically driven mineral precipitation in anaerobic biofilms. Water Sci. \& Technol. 39 (1999) 57-64.

19. A. Wanko, R. Mose, C. Beck, Biological Processing Capacities and Biomass Growth in Waste Water Treatment by Infiltration On two Kinds of Sand, Water Air Soil Pollut. 165 (2005) 279-299.

20. M. Pell, F. Nyberg, Infiltration of Wastewater in a Newly Started Pilot Sand-Filter System: III. Transformation of nitrogen, J. Environ. Qual. 18 (4) 463-467.

21. S. Van Cuyk, R. Siegrist, A. Logan, S. Masson, E. Fischer, L. Figueroa, Hydraulic and purification behaviors and their interactions during wastewater treatment in soil infiltration systems, Water Res. 35 (2001) 953-964.

22. M. Pell, F. Nyberg, H. Ljunggren, Microbial numbers and activity during infiltration of septic-tank effluent in subsurface sand filter, Water Res. 24 (1990) 1347-1354.

23. M. G. Healy, M. Rodgers, J. Mulqueen, Treatment of dairy wastewater using constructed wetlands and intermittent sand filters, Bioresour. Technol. 98 (2007) 2268-2281.

24. M. Rodgers, M. G. Healy, J. Mulqueen, Organic carbon removal and nitrification of high strength wastewaters using stratified sand filters, Water Res. 39 (2005) 3279-3286.

25. A. K. Bandick, R. P. Dick, Field management effects on soil enzyme activities, Soil Biology \& Biochem. 31 (1999) 1471-1479.

26. A. Hedström, L. R. Amofah, Adsorption and desorption of ammonium by clinoptilolite adsorbent in municipal wastewater treatment systems, J. Environ. Eng. Sci. 7 (2008) 53-61.

27. R. L. Siegrist, W. C. Boyle, Wastewater-induced soil clogging development, J. Env. Eng. 113 (1987) 550-566.

28. A. Schwager, M. Boller, Transport phenomena in intermittent filters, Water Sci. 
Technol. 35 (1997) 13-20.

29. M. Ardakani, J. Rehbock, A. McLaren, Oxidation of ammonium to nitrate in a soil column, Soil Sci. So. Am. J. 38 (1974) 96-99.

30. A. Jacobs, F. Lafolie, J. M. Herry, M. Debroux, Kinetic adhesion of bacterial cells to sand: Cell surface properties and adhesion rate. Colloids and Surfaces B: Biointerfaces. 59 (2007) 35-45.

31. P. R. Rout, P. Bhunia, R. R. Dash, Evaluation of kinetic and statistical models for predicting breakthrough curves of phosphate removal using dolochar-packed columns, Journal of Water Process Engineering. 17 (2017) 168-180

32. M. Bahgat, A. Dewedar, A. Zayed, Sand-filters used for wastewater treatment: buildup and distribution of microorganisms, Water Res. 33 (1999) 1949-1955.

33. A. Hedström, L. R. Amofah, Adsorption and desorption of ammonium by clinoptilolite adsorbent in municipal wastewater treatment systems, J. Environ. Eng. Sci. 7 (2008) 53-61. 
Table 1: Packing material characteristics

\begin{tabular}{|c|c|c|c|c|}
\hline Filter material & $\begin{array}{c}\text { River sand } 1 \\
\text { (RS1) }\end{array}$ & $\begin{array}{c}\text { River sand } 2 \\
\text { (RS2) }\end{array}$ & $\begin{array}{c}\text { Crushed } \\
\text { aggregate } 1 \\
\text { (CA1) }\end{array}$ & $\begin{array}{c}\text { Crushed } \\
\text { aggregate } 2 \\
\text { (CA2) }\end{array}$ \\
\hline Picture & 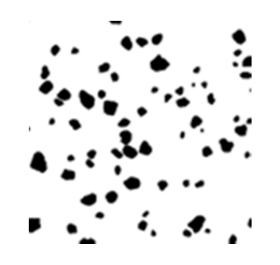 & 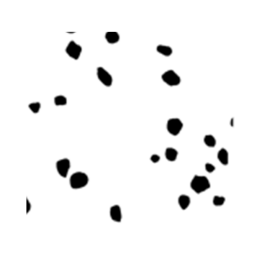 & 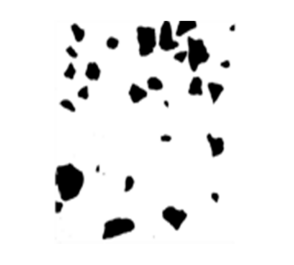 & $\begin{array}{r}\because . \bullet \\
.0 \\
. \bullet\end{array}$ \\
\hline $\begin{array}{l}\text { Effective size } \mathrm{D}_{10} \\
\qquad(\mathrm{~mm})\end{array}$ & 0.38 & 1.60 & 0.17 & 0.44 \\
\hline $\begin{array}{l}\text { Average diameter } \mathrm{D}_{\mathrm{m}} \\
\qquad(\mathrm{mm})\end{array}$ & 0.82 & 2.26 & 1.36 & 1.6 \\
\hline $\begin{array}{l}\text { Uniformity coefficient } \\
\text { (UC) }\left(\mathrm{D}_{60} / \mathrm{D}_{10}\right)\end{array}$ & 2.78 & 1.75 & 10 & 5 \\
\hline Circularity & $0.849( \pm 0.060)$ & $0.819( \pm 0.037)$ & $0.824( \pm 0.088)$ & $0.800( \pm 0.109)$ \\
\hline Roundness & $0.74( \pm 0.11)$ & $0.76( \pm 0.10)$ & $0.73( \pm 0.15)$ & $0.67( \pm 0.15)$ \\
\hline Fine particles $(\%)$ & $0.4 \%$ & $0.5 \%$ & $5 \%$ & $2.4 \%$ \\
\hline Porosity [min, max] & {$[30 \%, 33 \%]$} & {$[37 \%, 41 \%]$} & {$[38 \%, 41 \%]$} & {$[38 \%, 44 \%]$} \\
\hline $\begin{array}{l}\text { Specific surface area } \\
\qquad\left(\mathrm{m}^{2} / \mathrm{kg}\right)\end{array}$ & 4.04 & 1.18 & 2.78 & 2.88 \\
\hline $\begin{array}{l}\text { Estimated hydraulic } \\
\text { conductivity }(\mathrm{m} / \mathrm{s})\end{array}$ & {$[8.25 \sim 9.53] \times 10^{-4}$} & - & {$[2.79 \sim 2.88] \times 10^{-4}$} & {$[7.49 \sim 9.73] \times 10^{-4}$} \\
\hline
\end{tabular}


Table 2: Reactors and feeding conditions

355

\begin{tabular}{cccccc}
\hline $\begin{array}{c}\text { Reactor number } \\
\text { in Fig. 1 }\end{array}$ & $\begin{array}{c}\text { Average } \\
\text { height } \\
(\mathrm{cm})\end{array}$ & Material & $\begin{array}{c}\text { Hydraulic } \\
\text { loading } \\
(\mathrm{cm} / \text { day })\end{array}$ & $\begin{array}{c}\text { Hydraulic } \\
\text { residence } \\
\text { time (HRT, } \\
\text { hours })\end{array}$ & $\begin{array}{c}\text { Variation in } \\
\text { O }_{2} \text { gas }\end{array}$ \\
\hline 1 & 15 & RS1 & 12 & - & - \\
2 & 15 & RS2 & 12 & - & - \\
3 & 15 & CA1 & 12 & - & - \\
4 & 15 & CA2 & 12 & - & - \\
5 & 30 & RS1 & 12 & 23 & - \\
6 & 30 & RS2 & 12 & 8 & - \\
7 & 30 & CA1 & 12 & 32 & - \\
8 & 30 & CA2 & 12 & 20 & - \\
10 & 70 & RS1 & 12 & 35 & {$[11,20] \%$} \\
11 & 70 & RS1 & 20 & 12 & - \\
12 & 70 & CA1 & 12 & 93 & {$[19.2,19.8] \%$} \\
\hline
\end{tabular}


Table 3: Feed water (septic effluent) characteristics

\begin{tabular}{|c|c|c|}
\hline Parameter & Average value & [min; max] \\
\hline $\mathrm{pH}(\mathrm{n}=5$ tests $)$ & 7.1 & {$[6.6 ; 7.5]$} \\
\hline TSS (mg/L, n=18) & $39( \pm 11)$ & {$[20 ; 66]$} \\
\hline VSS (mg/L, n=1) & 23 & - \\
\hline $\mathrm{COD}\left(\mathrm{mgO}_{2} / \mathrm{L}, \mathrm{n}=18\right)$ & $372( \pm 100)$ & {$[231 ; 572]$} \\
\hline Tot-N (mgN/L, $\mathrm{n}=18)$ & 81 & {$[58 ; 95]$} \\
\hline $\mathrm{NH}_{4}{ }^{+}(\mathrm{mgN} / \mathrm{L}, \mathrm{n}=22)$ & $46( \pm 21)$ & {$[20 ; 77]$} \\
\hline $\mathrm{NO}_{2}^{-}(\mathrm{mgN} / \mathrm{L}, \mathrm{n}=1)$ & $<0.01$ & - \\
\hline $\mathrm{NO}_{3}^{-}(\mathrm{mgN} / \mathrm{L}, \mathrm{n}=22)$ & $<2.3$ & {$[0 ; 2.3]$} \\
\hline $\mathrm{PO}_{4}{ }^{3-}(\mathrm{mgP} / \mathrm{L}, \mathrm{n}=14)$ & 9 & {$[7.2 ; 12.7]$} \\
\hline $\begin{array}{l}\text { Viable aerobic flora }\left(37^{\circ} \mathrm{C}\right) \\
\qquad\left(\mathrm{CFU}^{*} / 100 \mathrm{~mL}\right)\end{array}$ & $5.1 \times 10^{5}$ & {$\left[9.5 \times 10^{4} ; 1.1 \times 10^{6}\right]$} \\
\hline
\end{tabular}




\begin{tabular}{|c|c|c|c|c|c|c|}
\hline \multirow[b]{2}{*}{ Reference } & \multirow[b]{2}{*}{ Location } & \multirow[b]{2}{*}{ Process type } & \multirow[b]{2}{*}{ Operating conditions } & \multicolumn{3}{|c|}{ Removal efficiencies (\%) } \\
\hline & & & & $\begin{array}{l}\text { COD or } \\
\mathrm{BOD}_{5}\end{array}$ & SS & $\begin{array}{c}\mathrm{NH}_{4}{ }^{+} \text {or } \\
\mathrm{TN}\end{array}$ \\
\hline $\begin{array}{l}\text { Molle et al. } \\
\quad \text { (2003) }\end{array}$ & France & $\begin{array}{l}\text { Vertical } \\
\text { flow } \\
\text { constructed } \\
\text { wetland }\end{array}$ & $\begin{array}{c}\mathrm{D}_{10}=0.22 \mathrm{~mm} \\
\mathrm{UC}=5.1\end{array}$ & 84 on $\mathrm{COD}$ & 95 & $\begin{array}{c}85 \text { on } \\
\text { TN }\end{array}$ \\
\hline $\begin{array}{l}\text { Torrens et } \\
\text { al. (2009) }\end{array}$ & France & Sand filter & $\begin{array}{c}\mathrm{D}_{10}=0.25 \mathrm{~mm}, \\
\mathrm{UC}=4.7, \text { depth=25 cm } \\
\text { of } \mathrm{RS}\end{array}$ & 42 on $\mathrm{COD}$ & 63 & $\begin{array}{l}82 \text { on } \\
\mathrm{NH}_{4}^{+}\end{array}$ \\
\hline $\begin{array}{l}\text { Neralla et } \\
\text { al. }(2000)\end{array}$ & USA & $\begin{array}{c}\text { Planted } \\
\text { horizontal } \\
\text { flow } \\
\text { constructed } \\
\text { wetland }\end{array}$ & $\begin{array}{l}30 \mathrm{~cm} \text { of } 0.95-\mathrm{cm} \\
\text { gravel media }\end{array}$ & 84 on $\mathrm{BOD}_{5}$ & 70 & - \\
\hline $\begin{array}{l}\text { Van Cuyk } \\
\text { et al. }(2000)\end{array}$ & USA & $\begin{array}{c}\text { Soil } \\
\text { lysimeter }\end{array}$ & $\begin{array}{c}\mathrm{D}_{10}=0.22 \mathrm{~mm}, \\
\mathrm{UC}=2.7, \text { depth}=60 \mathrm{~cm} \\
\text { of aggregate free soil }\end{array}$ & $\begin{array}{c}97 \text { on } \mathrm{COD} \\
/ 83 \text { on } \\
\mathrm{BOD}_{5}\end{array}$ & 84 & $\begin{array}{c}3 \text { on } \\
\mathrm{TN} / \\
100 \text { on } \\
\mathrm{NH}_{4}{ }^{+}\end{array}$ \\
\hline $\begin{array}{l}\text { Elbana } \text { et } \\
\text { al. }(2012)\end{array}$ & USA & Sand filter & $\begin{array}{c}\mathrm{D}_{10}=0.32 \mathrm{~mm}, \\
\mathrm{UC}=3.2, \text { depth}=50 \mathrm{~cm} \\
\text { of } \mathrm{RS}\end{array}$ & - & 60 & - \\
\hline $\begin{array}{l}\text { Gill et al. } \\
\text { (2009) }\end{array}$ & Ireland & Soil trench & $\begin{array}{c}\text { depth }=30 \mathrm{~cm} \text { of sandy } \\
\text { soil }\end{array}$ & 77 on $\mathrm{COD}$ & - & $\begin{array}{l}59-89 \\
\text { on } \mathrm{TN}\end{array}$ \\
\hline $\begin{array}{l}\text { Rodgers et } \\
\text { al. }(2011)\end{array}$ & Ireland & Sand filter & $\begin{array}{c}\mathrm{D}_{10}=1 \mathrm{~mm}, \mathrm{UC}=2.95 \\
\text { depth=30 } \mathrm{cm} \text { of } \mathrm{RS}\end{array}$ & 82 on COD & 74 & $\begin{array}{l}92 \text { on } \\
\mathrm{NH}_{4}^{+}\end{array}$ \\
\hline $\begin{array}{l}\text { Pramanik et } \\
\text { al. (2015) }\end{array}$ & & Sand filter & Depth $=50 \mathrm{~cm}$ of $\mathrm{RS}$ & 45 on DOC & - & $\begin{array}{l}89 \text { on } \\
\mathrm{NH}_{4}^{+}\end{array}$ \\
\hline
\end{tabular}

Table 4: Historic data of similar processes aimed at the treatment efficiencies of key pollutants 
Table 5: Treatment efficiencies (\% removals) of filtration reactors with two selected materials (RS1 and CA1) under different operating conditions

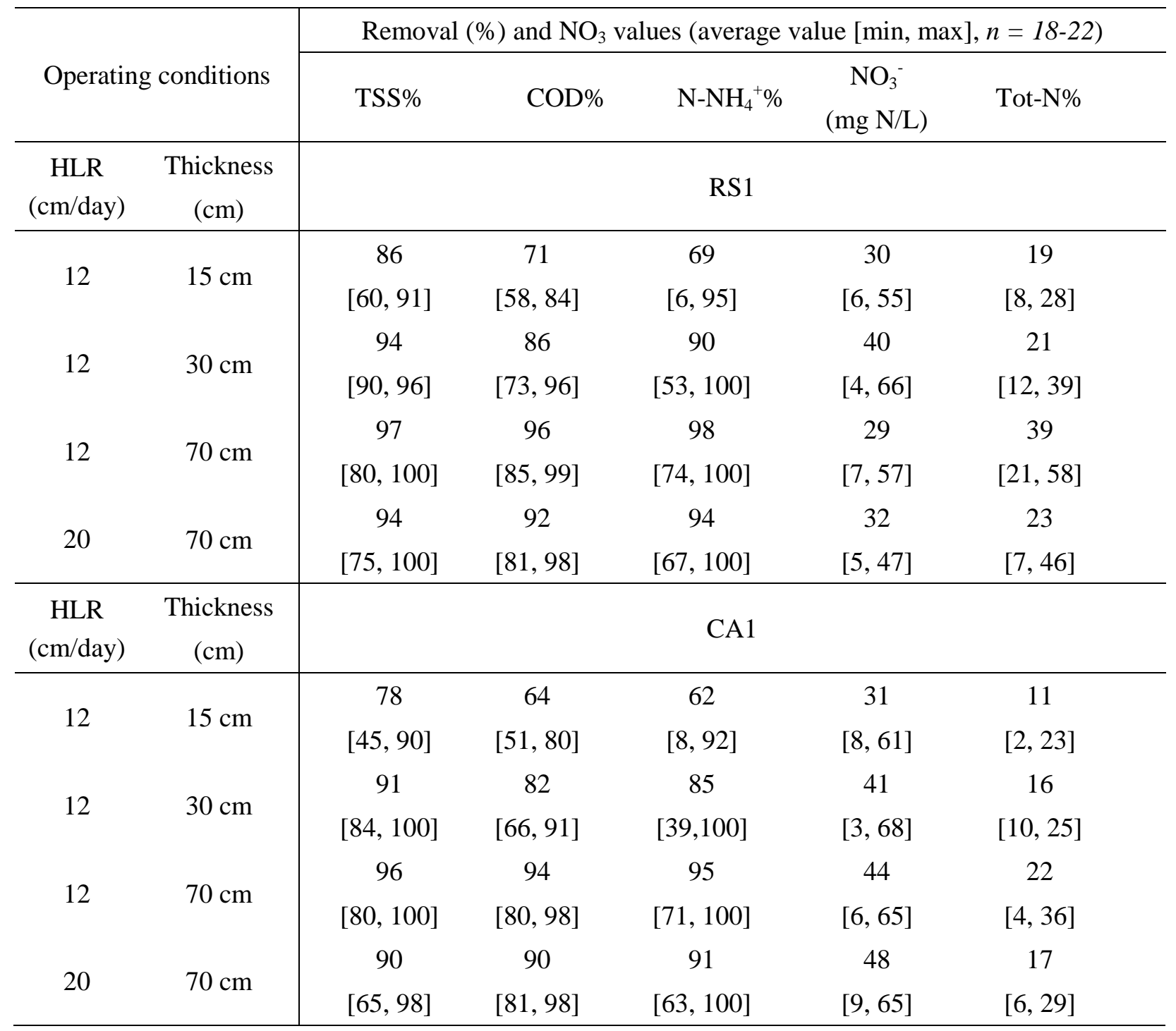


Table 6: Distribution of total organic matter in four materials at 360 days

\begin{tabular}{ccccc}
\hline $\begin{array}{c}\text { Layer: VDW } \\
\text { (mg/g of } \\
\text { aggregate) }\end{array}$ & RS1 & RS2 & CA1 & CA2 \\
\hline $0 \sim 5 \mathrm{~cm}$ & 12.49 & 3.69 & 10.03 & 8.01 \\
$10 \sim 15 \mathrm{~cm}$ & 4.10 & 2.19 & 4.81 & 5.21 \\
$30 \mathrm{~cm}$ & 2.98 & 1.63 & 3.39 & 3.56 \\
\hline VDW decreasing & $76 \%$ & $56 \%$ & $66 \%$ & $56 \%$ \\
from 0 30 cm $(\%)$ & & & & \\
\hline
\end{tabular}

381

382

383

384

385

386

387

388

389

390

391

392

393

394

395

396

397

398

399

400

401

402

403

404

405 

materials at 360 days

409

\begin{tabular}{cccc}
\hline $\begin{array}{c}\text { Heterotrophic flora } \\
\text { (CFU*/g of material })\end{array}$ & $\mathrm{RS} 1$ & $\mathrm{CA} 1$ & $\mathrm{CA} 2$ \\
\cline { 2 - 4 } $0 \sim 5 \mathrm{~cm}$ & $4.7 \times 10^{7}$ & $4.28 \times 10^{6}$ & $2.30 \times 10^{6}$ \\
& {$\left[2.5 \times 10^{7} ; 6.9 \times 10^{7}\right]$} & {$\left[2.2 \times 10^{6} ; 6.3 \times 10^{6}\right]$} & {$\left[1.2 \times 10^{6} ; 3.4 \times 10^{6}\right]$} \\
$10 \sim 15 \mathrm{~cm}$ & $4.98 \times 10^{7}$ & $2.98 \times 10^{6}$ & $1.25 \times 10^{6}$ \\
& {$\left[2.6 \times 10^{7} ; 7.3 \times 10^{7}\right]$} & {$\left[1.6 \times 10^{6} ; 4.4 \times 10^{6}\right]$} & {$\left[6.6 \times 10^{5} ; 1.9 \times 10^{6}\right]$} \\
$30 \mathrm{~cm}$ & $5.05 \times 10^{5}$ & $2.93 \times 10^{6}$ & $1.66 \times 10^{6}$ \\
& {$\left[2.7 \times 10^{5} ; 7.5 \times 10^{5}\right]$} & {$\left[1.5 \times 10^{6} ; 4.3 \times 10^{6}\right]$} & {$\left[8.7 \times 10^{5} ; 2.4 \times 10^{6}\right]$} \\
\hline Nitrifying flora & $\mathrm{RS} 1$ & $\mathrm{CA} 1$ & $\mathrm{CA} 2$ \\
$(\mathrm{MPN} / \mathrm{g}$ of material $)$ & 20 & 130 & 50 \\
\cline { 2 - 4 } $0 \sim 5 \mathrm{~cm}$ & {$[12 ; 48]$} & {$[78 ; 312]$} & {$[30 ; 120]$} \\
& $6.00 \times 10^{3}$ & $1.80 \times 10^{3}$ & $3.50 \times 10^{3}$ \\
$10 \sim 15 \mathrm{~cm}$ & {$\left[3.6 \times 10^{3} ; 1.4 \times 10^{4}\right]$} & {$\left[1.1 \times 10^{3} ; 4.3 \times 10^{3}\right]$} & {$\left[2.1 \times 10^{3} ; 8.4 \times 10^{3}\right]$} \\
& $\mathrm{N} / \mathrm{A}$ & $9.00 \times 10^{2}$ & $6.00 \times 10^{3}$ \\
$30 \mathrm{~cm}$ & {$\left[5.4 \times 10^{2} ; 2.2 \times 10^{3}\right]$} & {$\left[3.6 \times 10^{3} ; 1.4 \times 10^{4}\right]$} \\
\hline
\end{tabular}


415

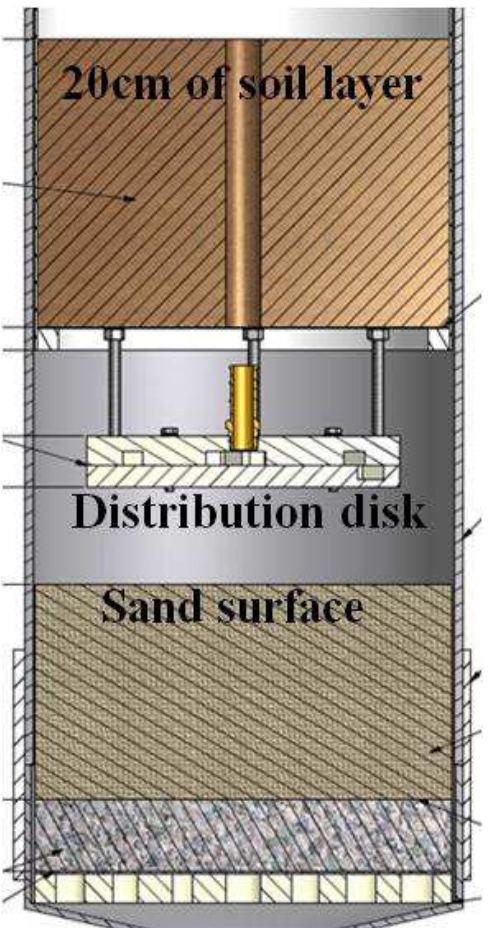

416

417 Figure 1: Overview of the pilot batch experiment at a laboratory scale

418 

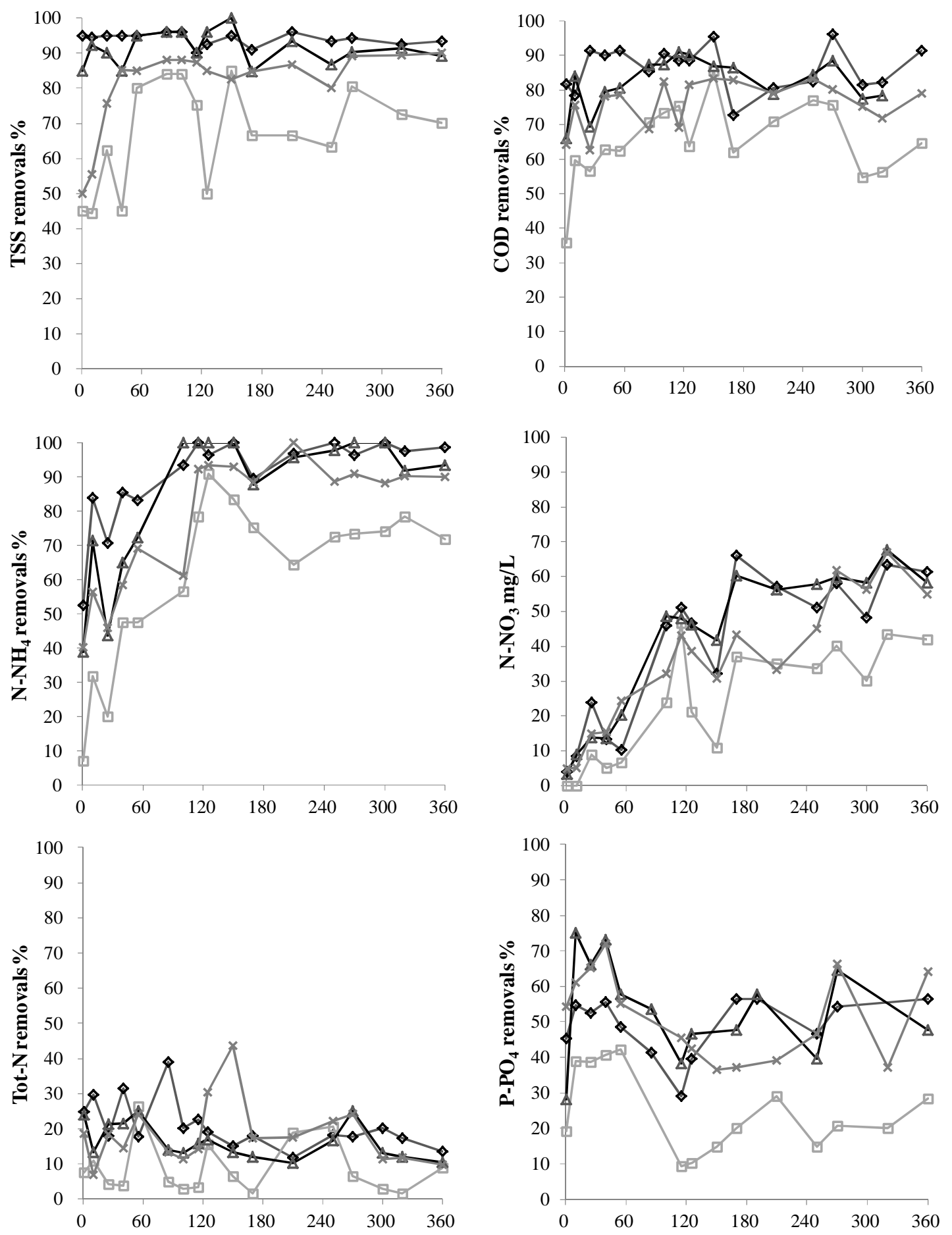

Operating time (days) $-30 \mathrm{~cm}$ reactors$$
\diamond \mathrm{RS1} \quad \square \mathrm{RS2} \quad \rightarrow \mathrm{CA1} \quad * \mathrm{CA2}
$$

Figure 2: Treatment efficiencies of $30-\mathrm{cm}$ reactors with four filter materials over a 360-day operating cycle

422 (a: TSS removals, in \%; b: COD removals, in \%; c: $\mathrm{N}_{-} \mathrm{NH}_{4}$ removals, in \%; 

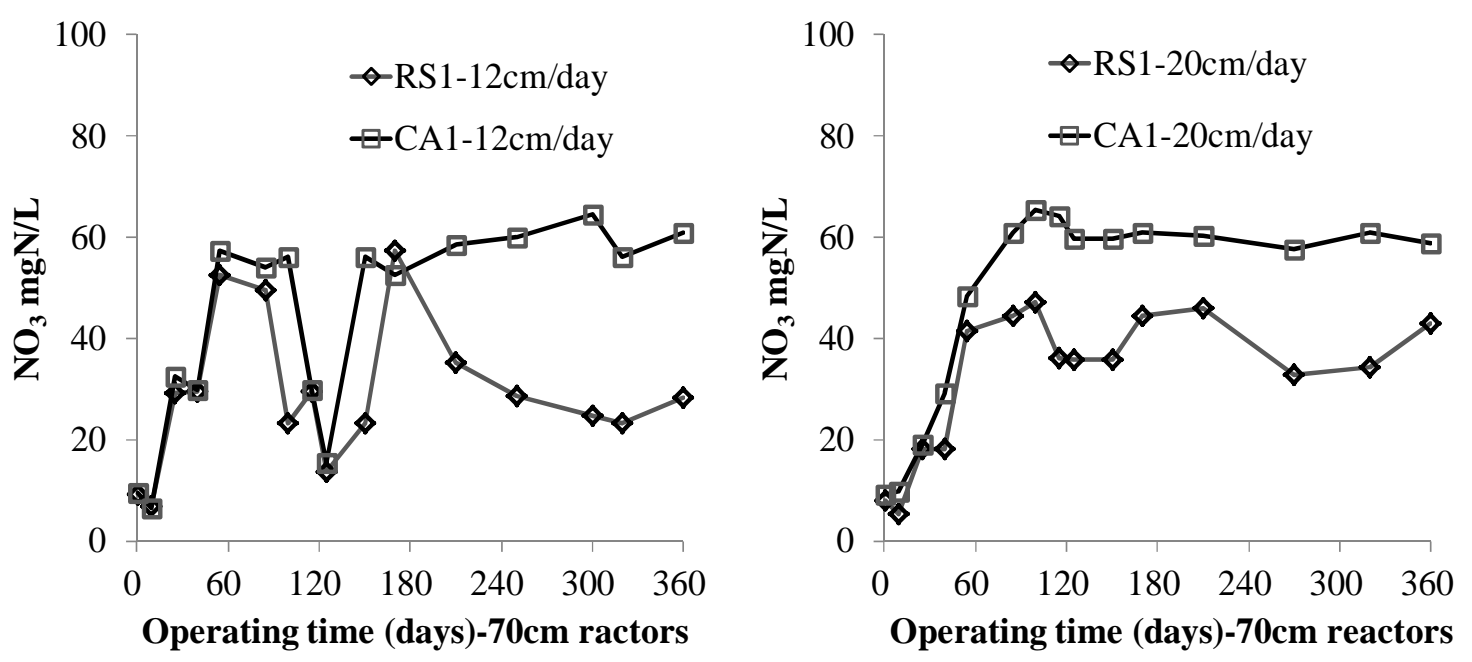

Figure 3: Nitrate ions removal efficiencies with $70-\mathrm{cm}$ reactors for two materials under different hydraulic loadings 

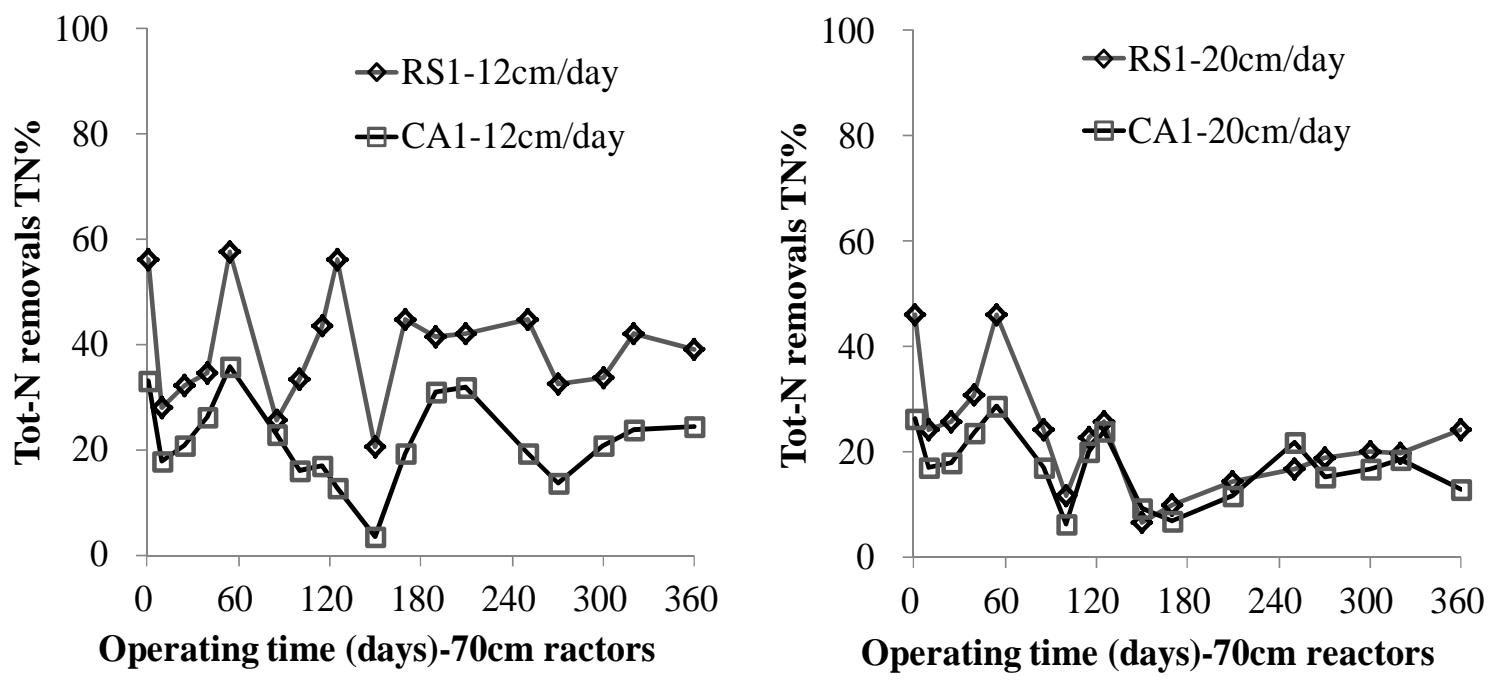

Figure 4: Total nitrogen removal efficiencies with $70-\mathrm{cm}$ reactors for two materials under different hydraulic loadings 
A

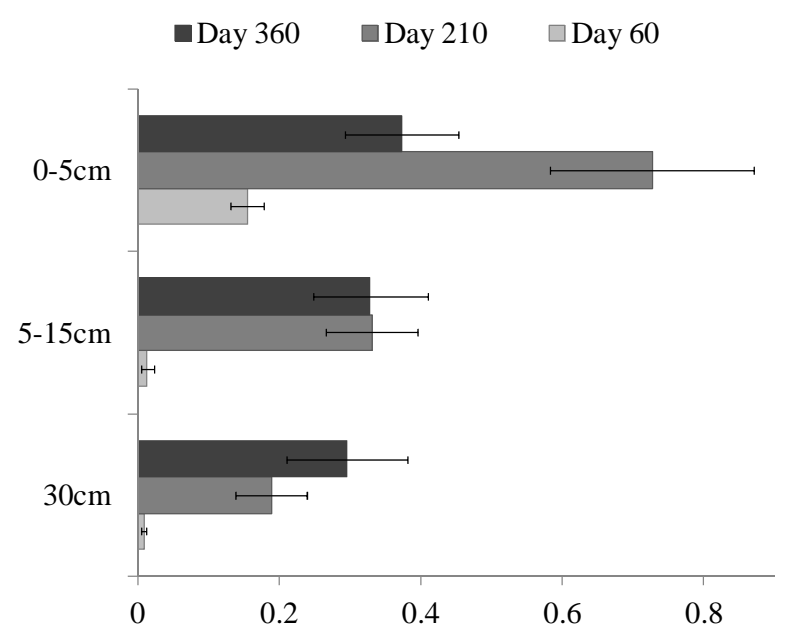

Abs at $490 \quad \mathrm{~nm} \quad \mathrm{AU} / \mathrm{g}$ material
B

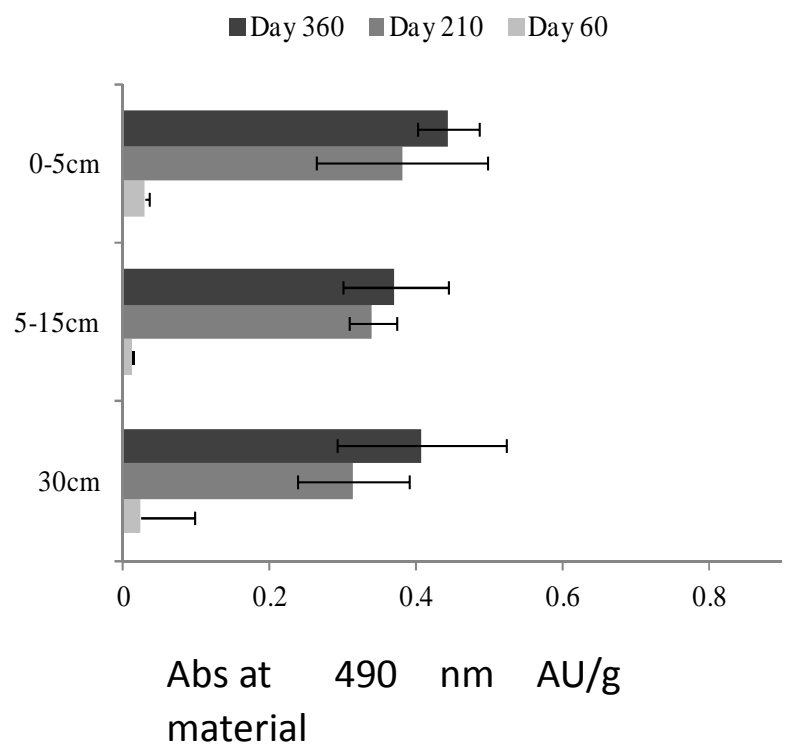

438 Figure 5: Changes in FDA hydrolysis activities in different depths in biofilter of CA1 and CA2 over 439 the operating period 


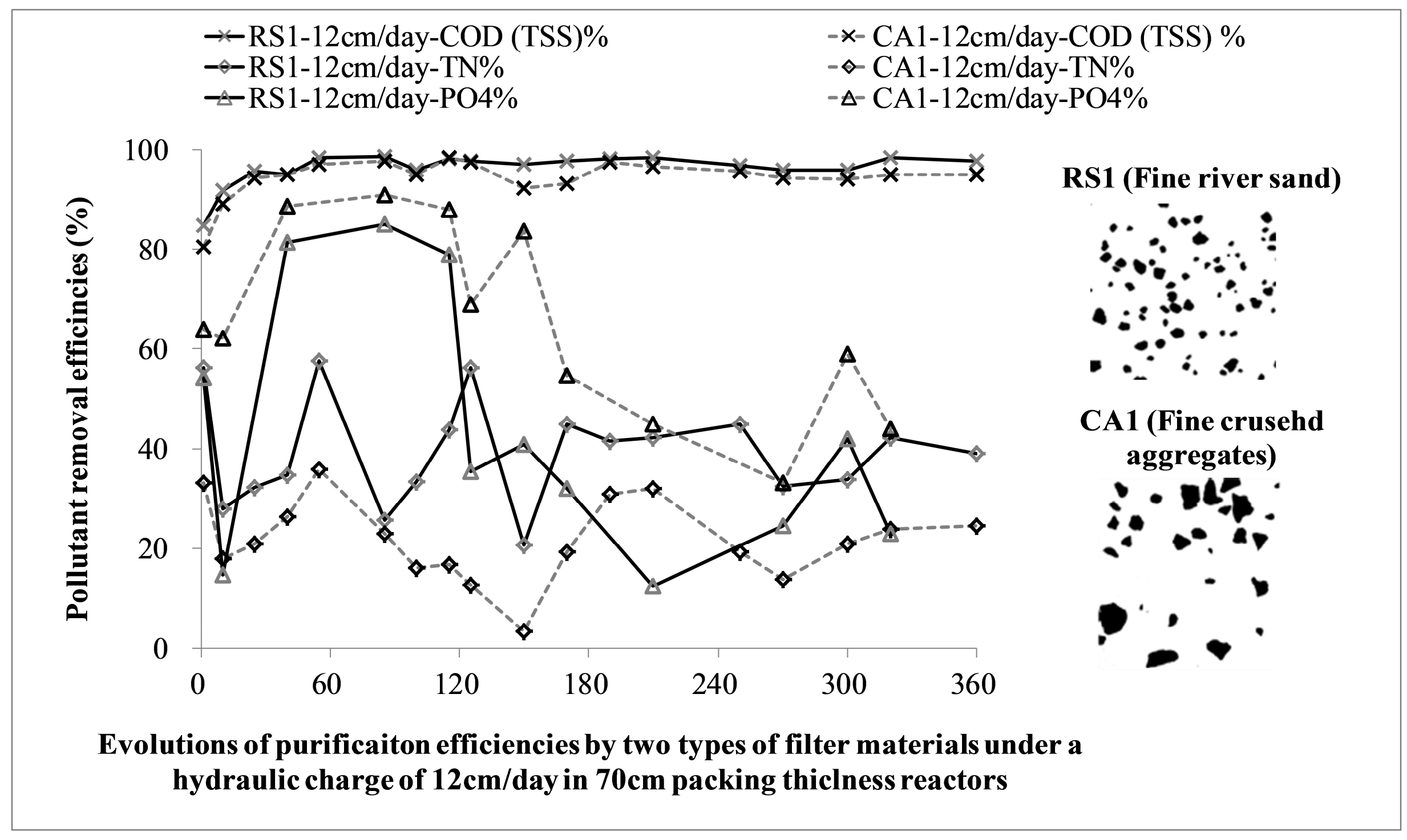

